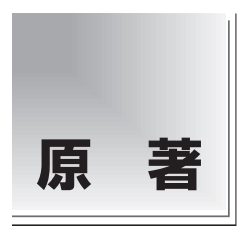

論文受付

2020 年 6 月 30 日

論文受理

2020 年 12 月 8 日

Code No. 261

\section{肝 MR エラストグラフィにおける加振強度の最適化： 適切な加振強度と体格指標との関係}

\author{
森 直人 中川貞裕 岩田邦弘
}

旭川医科大学病院診療技術部放射線技術部門

\section{緒 言}

慢性肝疾患に㧍いて, 線維化は重要な病態判断の指 標になる，進行性の肝線維化は門脈圧の立進や肝がん 発生につながることが明らかになっておりり ${ }^{1,2)}$, 線維化 の程度を診断することは非常に重要である。肝線維化 診断に扮ける gold standard は肝生検である。しか し，その侵襲性，コスト，病理医間の読影の不一致と いった諸問題から，簡便かつ精度の高い非侵襲的診断 法の開発が望まれている3). Magnetic resonance (MR) imaging を利用した肝 MR elastography (MRE) による肝弾性率測定は，非侵襲的で客観性に優れてお
り，肝線維化診断の信頼性も高いことが報告されてい $ろ^{4,5)}$. MRE は, 外部加振装置により対象臟器に振動 を与え, この振動と同期した勾配磁場を与えることに より位相画像を取得し，その位相画像を特殊な計算ア ルゴリズムで処理して elastogram と呼ばれる硬度 マップ(stiffness map)を得る ${ }^{6)}$. 弾性率は硬度マップ から取得するが, 先行研究では MREにおいて, 画像 の signal-to-noise ratio (SNR) や呼吸のアーチファク ト，ならびに各種撮像条件が弾性率に影響を及ぼすこ とが明らかになっている6 . 特に撮像条件に関して, motion encoding gradient (MEG) 周波数や外部加振周

\title{
Optimization of External Driver Amplitude in Magnetic Resonance Elastography of the Liver: Relationship between Appropriate External Driver Amplitude and Indicators of Physical Constitution
}

\author{
Naoto Mori, ${ }^{*}$ Sadahiro Nakagawa, and Kunihiro Iwata \\ Section of Radiological Technology, Department of Medical Technology, Asahikawa Medical University Hospital
}

Received June 30, 2020; Revision accepted December 8, 2020

Code No. 261

\begin{abstract}
Summary
Purpose: Magnetic resonance elastography (MRE) of the liver was performed to examine the appropriate external driver amplitude according to the physique of the subject and the index useful for determining the physique. Methods: For 60 subjects who underwent MRE examination, we measured the unmeasurable elastic modulus area in the liver based on the stiffness map obtained from MRE. The external driver amplitude with the smallest unmeasurable elastic modulus area was taken as the appropriate external driver amplitude for the subject. The receiver operating characteristic (ROC) analysis was performed on the indicators of physical constitution (abdominal depth, waist circumference, body weight and body mass index (BMI) ) and external driver amplitude of $30 \%, 50 \%$ and $70 \%$. BMI was the most appropriate tool for the comparison of indicators of physical constitution. Result: The appropriate external driver amplitude was $30 \%$ when the cutoff value of BMI was less than $25.3 \mathrm{~kg} / \mathrm{m}^{2}$, $70 \%$ when it was $31.0 \mathrm{~kg} / \mathrm{m}^{2}$ or more, and $50 \%$ when it was between them. Conclusion: It is considered that an accurate elastic modulus can be obtained by setting an appropriate indicator of physical constitution and external driver amplitude according to physique in MRE.
\end{abstract}

Key words: external driver amplitude, magnetic resonance elastography (MRE), liver, indicators of physical constitution

*Corresponding author 
波数, スライス厚に関する報告はされているが7)，加 振強度に関する詳細な検討は報告されていない. MREの撮像パラメータの一つである加振強度は, 体 格の大柄な被検者に弱い場合や，小柄でやせている被 検者に強い場合には，位相画像上で位相差がうまく付 かないことにより，計測する硬度マップに影響するこ

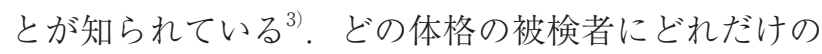
加振強度が適切なのか, また, 加振強度を分類する適 切な指標が明らかになれば，良好な弾性率の取得が期 待できる. 本研究の目的は, 肝 MREにおいて体格ご との適切な加振強度や, それを決定する際の適切な体 格指標を明らかにすることである。

\section{1. 方 法}

\section{1-1 対象}

対象は当院において 2017 年 7 月 25 日〜2018 年 8 月までに肝 MRE 検査を受けた 63 名すべての被検者 とした。そのうち，MRE 撮像において息止め不良が あり，波画像上で明らかなせん断波がない場合や $\mathrm{T}_{1}$ 強調画像と MRE で解剖学的に明らかなずれが生じた 3 名を対象外とし, 最終的に 60 名 (男性: 26 名, 女性： 34 名, 年歯 17-86 歳, 平均 57.5 114.3 歳, 身長 $142.2-180 \mathrm{~cm}$, 平均 $161.5 \mathrm{~cm} \pm 8.4 \mathrm{~cm}$, 体重 31-136.5 $\mathrm{kg}$, 平均 $72.0 \pm 17.6 \mathrm{~kg}$, 体厚 $15.75-27.1 \mathrm{~cm}$, 平均 21.72 $\pm 3.57 \mathrm{~cm}$ ，体周囲長 63.8-124.93 cm，平均 95.70 \pm 13.59 $\mathrm{cm}$, BMI 13.8-44.71 kg/m², 平均 $27.62 \pm 6.14 \mathrm{~kg} / \mathrm{m}^{2}$ ) を対象とした。症例の内訳は非アルコール性脂肪肝 炎/非アルコール性脂肪肝疾患 $(n=35), B$ 型肝硬変 $(n=$ 5), B 型肝炎 $(n=9)$, 肝細胞がん $(n=3)$, アルコール性 肝疾患 $(n=5), C$ 型肝炎 $(n=3)$ であった。いずれの被検 者も腹水はなかった。 なお, 本研究は当施設の臨床研 究倫理審査委員会の承認を受けて実施した。被検者の データの取り扱いについては, データ解析において被 検者個人に連結可能な符号を付して対応表を作成し データを取り扱った。

\section{1-2 使用機器・撮像条件}

MR 装置は Discovery MR 750w 3.0 T (GE Healthcare, Milwaukee, WI, USA), 受信コイルは GEM Anterior array coil を使用した。肝門部より若干上 で，肝蔵ができるだけ広範囲に描出された横断面を含 む 10 スライスの $\mathrm{T}_{1}$ 強調画像および MRE 撮像を実施 した. $\mathrm{T}_{1}$ 強調画像は2-dimentional(2D)の gradientrecalled echo 法の opposed-phase を用いた。撮像条件 は, repetition time(TR) : $180 \mathrm{~ms}$, echo time(TE) : 1.2, $2.5 \mathrm{~ms}$, マトリクス : $192 \times 320$, スライス枚数: 10,
スライス厚 : $10 \mathrm{~mm}$, field-of-view $(\mathrm{FOV}): 42 \mathrm{~cm}$, flip angle : $60^{\circ}$, 受信バンド幅: $166.7 \mathrm{kHz}$, 撮像時間 : 18 秒である。また MRE 撮像では $2 \mathrm{D}$ spin-echo echoplanar imaging (SE-EPI) を使用して $\mathrm{T}_{1}$ 強調画像を指 標に同範囲の撮像を行った，MREの撮像条件に関し て, 単位時間あたりの傾斜磁場変動 $(\mathrm{dB} / \mathrm{dt})$, 比吸収 率はともに first level, TR : $1000 \mathrm{ms,}$ TE : $59.2 \mathrm{ms,}$ $\mathrm{FOV}: 42 \mathrm{~cm}$, スライス枚数 : 10 枚, スライス厚 : 10 $\mathrm{mm}$, スライス間隔: $4 \mathrm{~mm}$, マトリクス : $64 \times 64, \mathrm{MEG}$ 周波数 : $80 \mathrm{~Hz}$, 加振周波数 : $60 \mathrm{~Hz}, \mathrm{MEG}$ 印加軸 : Z, 受信バンド幅 : $250 \mathrm{kHz}$, 撮像時間 : 16 秒とした. 加 振方法は, 振動発生装置に取り付けられた直径 $19 \mathrm{~cm}$ のパッシブ空気圧ドライバを, 剣状突起より $5 \mathrm{~cm}$ 右 側の肝右葉中心付近に配置し, 固定用バンドを巻いて 固定した。発生させた振動波を空気チューブからパッ シブ空気圧ドライバにより被検者の腹部に振動を与え た. MRE 撮像に用いた加振強度は 30, 50, 70\%とし， それぞれ 2 回ずつスキャンを行った。画像合成・計測 には SYNAPSE VINCENT（富士フイルムメディカ ル，東京）を使用した。

\section{1-3 画像解析}

体格に応じた適切な加振強度の評価には, MRE か ら取得した cross-hatching 付きの硬度マップ(以下, 硬度マップ)において, 肝臓領域に対するcrosshatching 領域の割合で評価した. Cross-hatching とは 硬度マップに表示される×印のことで3), SNR や波の 平行性を考慮し, 弾性率の測定不能領域が自動的に表 示されたもので, region of interest (ROI) 設定の際の 目安となる3)。硬度マップ上において cross-hatching がない面積は, 弾性の測定可能な「正しく計算された 面積」を表す ${ }^{8)}$.

\section{1-4 体格指標の選定}

体格に合わせた加振強度を分類するための, 体格指 標を検討した。体格指標の候補として，実際に検査を 行ううえで簡便に知ることができる (a) 体厚, (b)体周 囲長, (c)体重, (d) ボディマス指数 (body mass index: BMI $)^{9)}$ を設定した。これらの候補の選定理由として, 体厚と体周囲長は，実際に体表面を摇らした際，波が 深部方向にしっかり伝わること, かつ, 波の反射や干 渉を考慮すると, 皮下脂肪のみではなく体の厚み, お よび体周囲の脂肪を考慮したほうがよいと考えた。実 測は解析時に計測し, 計測スライスは実際に測定不能 領域を計測した硬度マップと同じスライス位置の $T_{1}$ 強調画像を使用した。体厚は体の腹背方向の直径を計 

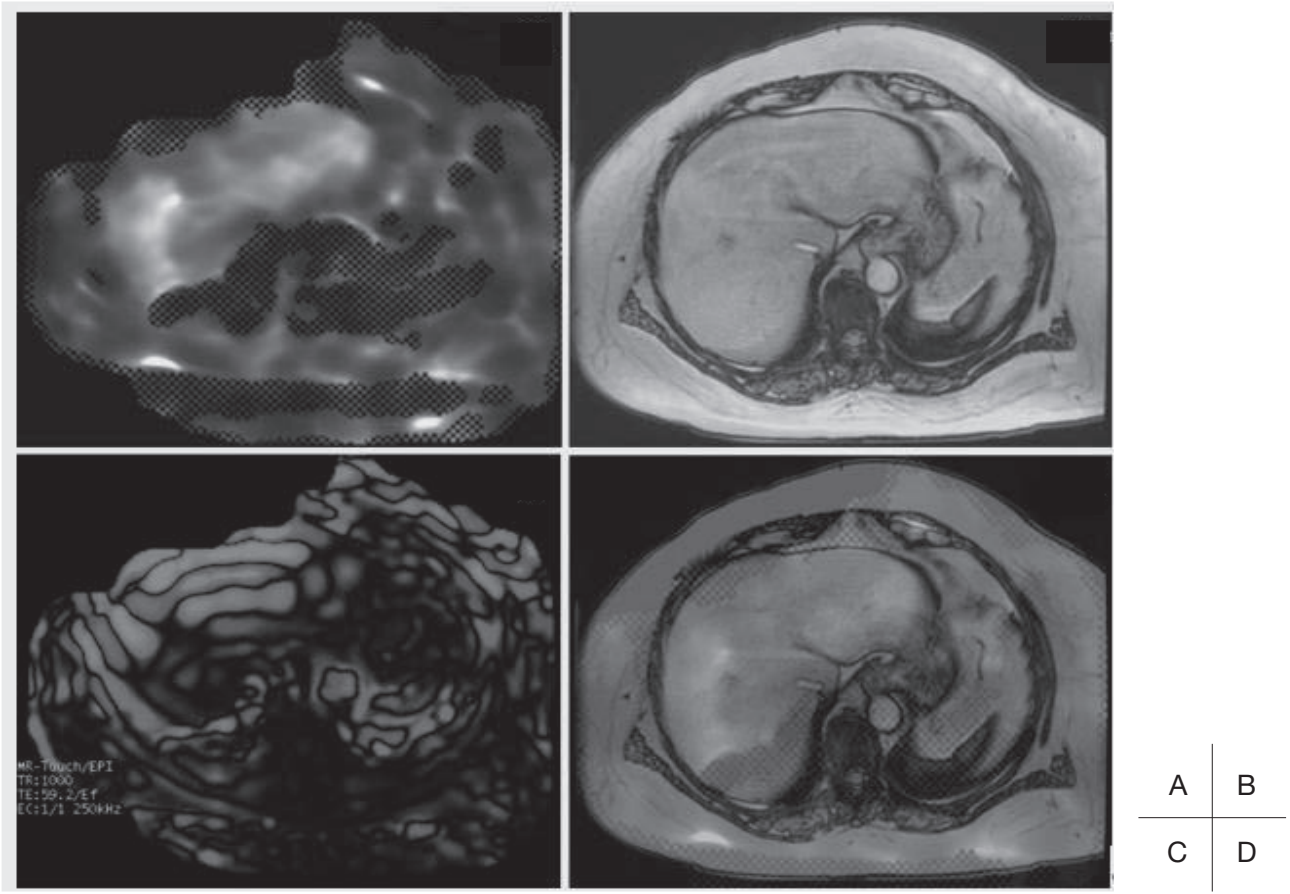

Fig. 1 Presentation of fused images.

(A) MRE image with cross-hatching marks

(B) Fused image of magnitude MR image and out-of-phase 2D $\mathrm{T}_{1}$-weighted image

(C) Wave image corresponding to the level of (A) and (B)

(D) Fused image of (A) and out-of-phase 2D $\mathrm{T}_{1}$-weighted image

MRE: magnetic resonance elastography, 2D: 2-dimentional

測し，体周囲長は体周囲の長さを計測した。

体重は電子カルテ上の患者基本情報や患者本人から 直接情報を得ることができる，BMIに関しては先行 研究10)において, MREに扔ける正常な肝臓の平均弾 性率はBMIに影響しないと報告されているが, 本研 究ではさまざまな病態や体型の被検者を対象としてい ることを考慮し，候補として設定した．

\section{1-5 硬度マップにおける弾性率測定不能領域の算出}

体格に応じた適切な加振強度を評価するため, 硬度 マップにおける肝内の cross-hatching 領域を計測した。 肝内の測定不能領域の割合を次式を用いて算出した。

弾性率測定不能領域の割合 $(\%)=\frac{\text { Cross - hatching領域 }}{\text { 肝面積 }} \times 100$

2 回ずつ撮像した加振強度 $30,50,70 \%$ における計 測した弾性率測定不能領域の割合は, 計測した測定值 を平均した，実際に計測する際，取得した硬度マップ のみでは画像上の肝臓を正確に特定することが困難な ため, 硬度マップと解剖学的画像用の $\mathrm{T}_{1}$ 強調画像で 合成画像を作成し, 透明度を調節して硬度マップと $\mathrm{T}_{1}$ 強調画像両方の視認性を最適化した ${ }^{11)}$. 更により 正確な評価を行うために, 硬度マップと MREの強度
画像を画像合成し, 二つの合成画像 (Fig. 1)を比較し ながら正確に位置を合わせ，計測した，計測するスラ イスの位置決めは，波画像上で心臓の動きの影響がな く, 波が一番平滑に伝播し, 硬度マップ上で画像欠損 が少ないスライスとした。硬度マップはMRE 撮像 後, 直接逆問題再構成法である multimodule direct inversion 法により生成されたものを用いた，本手法は 従来の multiscale direct inversion 法に比べ高い分解 能, ノイズの低減, 画像再構成時間の短縮などの利点 がある ${ }^{12,13)}$.

\section{1-6 加振強度に対する評価}

Yoshimitsu らの示す, ROC 解析を用いた肝臟の線 維化グレードの識別方法 ${ }^{14)}$ を参照し, 体格に応じた適 切な加振強度の評価を行った。体格に応じた適切な加 振強度を決定するため, 最も弾性率測定不能領域の少 ない加振強度を被検者の適切な加振強度とし, (1) $30 \%$ 群と 50\% 以上群 (50,70\%), (2) 50\%以下群 (30, $50 \%)$ と $70 \%$ 群で, receiver operating characteristic (ROC) 解析を行い, それぞれの体格指標において, area under curve (AUC) 值を算出・比較した。 またそ れぞれの体格指標におけるカットオフ值を算出し, 被 検者の体格に応じた適切な加振強度を検討した。 


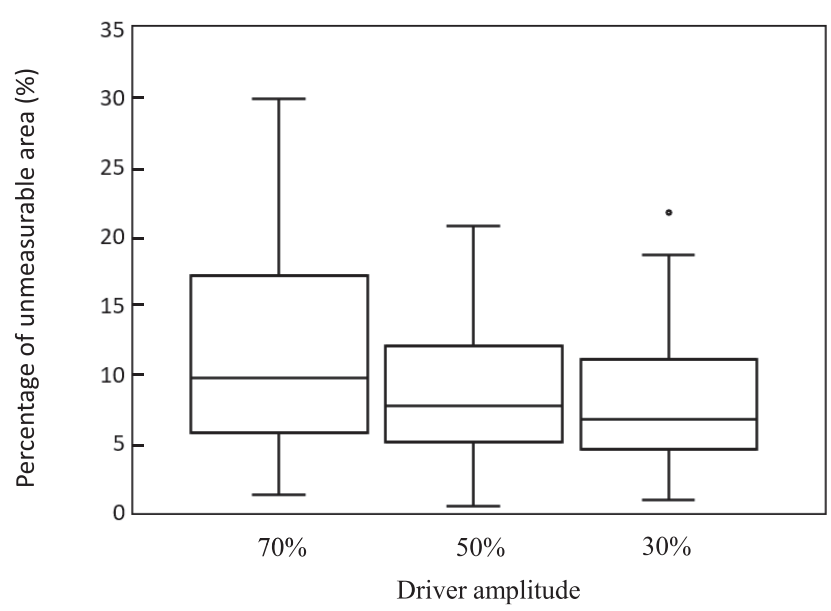

Fig. 2 Unmeasurable area of elastic modulus at each driver amplitude: all patients.

The upper ends of boxes indicate the third quartile and the bottom ends of boxes the first quartile, and lines in the box plot the median. The upper whiskers indicate the maximum and the lower whiskers the minimum, and the black coin is outliers.

$\mathrm{ROC}$ 曲線の作成， AUC 值の算出，カットオフ值の算 出には R version 3.5.0 (R Core Team, Vienna, Austria, package: ROCR $)^{15)}$ を用いた. AUC 值の比較には, Bonferroni の補正を用いて AUC 值の差の検定を行っ た。統計学的有意差は $\mathrm{P}<0.05$ を有意と判定した。ま た，最も適切な体格指標に対し，設定した適切な加振 強度が実際に硬度マップ上で弾性率測定不能領域がど の程度改善されたのか, カットオフ值の妥当性を検討 するために，統計学的有意差の検討を行った，方法は 対応のある $\mathrm{t}$ 検定を用い, $\mathrm{P}<0.05$ を有意差ありと判定 した。

\section{2. 結 果}

\section{2-1 硬度マップにおける弾性率測定不能領域の算出} 結果

1-5 項における，全被検者に対する弾性率測定不能 領域の割合を加振強度 30，50，70\%に分類し，Fig. 2 に示す。弾性率測定不能領域の割合の中央值, 最小值 および最大值は，加振強度 30\%で $6.67 ， 0.87 ， 21.67 \%$, 加振強度 $50 \%$ で $7.68,0.44,20.70 \%$, 加振強度 70\% で 9.65，1.20，29.90\%であった.

\section{2-2 各体格指標における AUC 值での比較}

1-6 項 (1)，（2）における各体格指標の感度・1-特異度 曲線を Fig. 3, 4 に, 各体格指標の AUC 值, 感度・特 異度の解析結果を Table 1，2 に示す. AUC 值を比較 すると，(1)では体厚に対して, 体周囲長, 体重, BMI

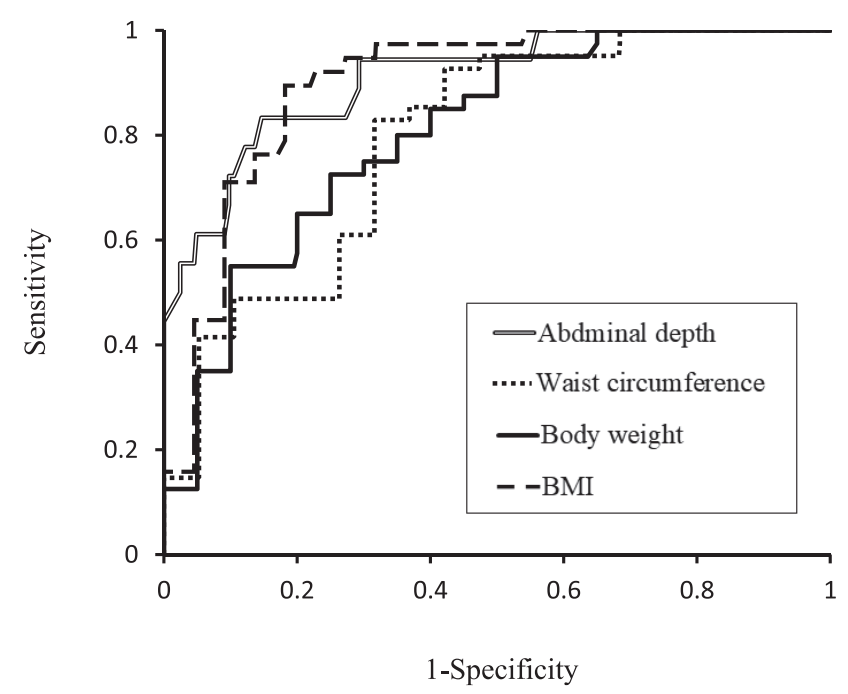

Fig. 3 ROC analysis to determine cut-off values in external driver amplitude $30 \%$ vs $50 \%$ and $70 \%$ for each indicators of physical constitution.

BMI: body mass index

ROC: receiver operating characteristic

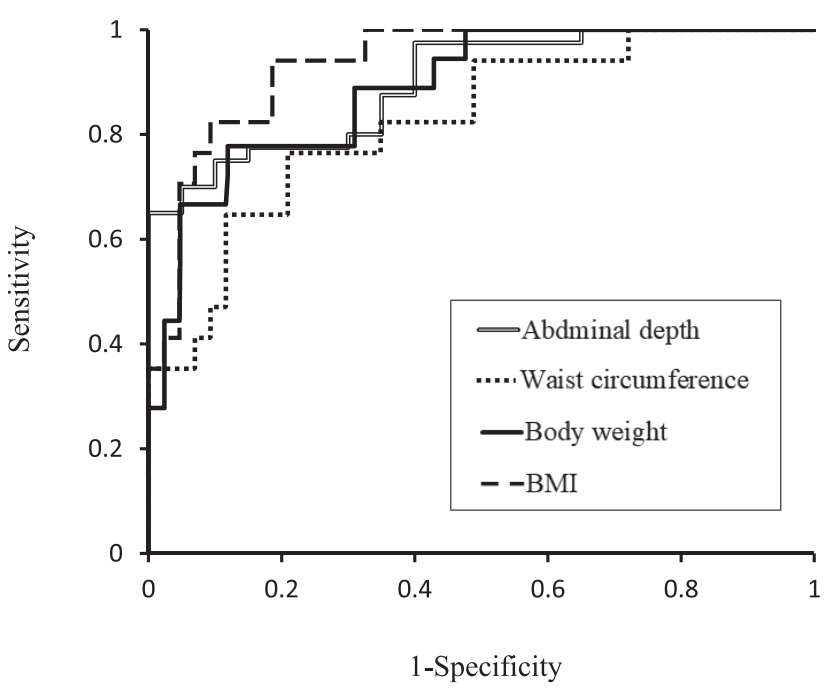

Fig. 4 ROC analysis to determine cut-off values in external driver amplitude $30 \%$ and $50 \%$ vs $70 \%$ for each indicators of physical constitution.

BMI: body mass index

ROC: receiver operating characteristic

ではいずれも有意差を認めなかった $(\mathrm{P}=0.42,0.3,1.0)$. 体周囲長に対して, 体重, BMI ではいずれも有意差は 認めなかった $(\mathrm{P}=1.0,0.78)$. BMI に対して体重では有 意差を認めた $(\mathrm{P}=0.04)$ 。（2)では体厚に対して，体周 囲長，体重，BMIではいずれも有意差を認めなかった $(\mathrm{P}=0.42,1.0,0.18)$. 体周囲長に対して, 体重, BMI で は有意差を認めなかった $(\mathrm{P}=1.0,0.12)$. BMI に対し て，体重では有意差を認めなかった $(\mathrm{P}=1.0)$. 以上よ 
Table 1 ROC analysis results of $30 \%$ vs $50 \%$ and $70 \%$ external driver amplitude for each indicators of physical constitution (abdominal depth, waist circumference, body weight and BMI)

\begin{tabular}{lcccc}
\hline $\begin{array}{c}\text { External driver amplitude } \\
\text { 30\% vs 50\% and 70\% }\end{array}$ & AUC & Sensitivity & Specificity & Cutoff \\
\hline Abdominal depth & 0.91 & 0.98 & 0.60 & $19.7(\mathrm{~cm})$ \\
Waist circumference & 0.79 & 0.93 & 0.58 & $88.1(\mathrm{~cm})$ \\
Body weight & 0.81 & 0.95 & 0.50 & $60.3(\mathrm{~kg})$ \\
BMI & 0.90 & 0.92 & 0.77 & $25.3\left(\mathrm{~kg} / \mathrm{m}^{2}\right)$ \\
\hline
\end{tabular}

BMI: body mass index, ROC: receiver operating characteristic

Table 2 ROC analysis results of $30 \%$ and $50 \%$ vs $70 \%$ external driver amplitude for each indicators of physical constitution (abdominal depth, waist circumference, body weight and BMI)

\begin{tabular}{lcccc}
\hline \hline $\begin{array}{c}\text { External driver amplitude } \\
30 \% \text { and 50\% vs 70\% }\end{array}$ & AUC & Sensitivity & Specificity & Cutoff \\
\hline Abdominal depth & 0.91 & 0.61 & 0.95 & $23.7(\mathrm{~cm})$ \\
Waist circumference & 0.83 & 0.65 & 0.88 & $108.6(\mathrm{~cm})$ \\
Body weight & 0.90 & 0.67 & 0.95 & $83.0(\mathrm{~kg})$ \\
BMI & 0.93 & 0.71 & 0.95 & $31.0\left(\mathrm{~kg} / \mathrm{m}^{2}\right)$ \\
\hline
\end{tabular}

BMI: body mass index, ROC: receiver operating characteristic

り, 加振強度を設定するうえで最適な体格指標はBMI であった，本研究ではさまざまな肝臓の疾患が含まれ ていたが, 各体格指標, 加振強度における感度・特異 度は高值を示した。

\section{2-3＼cjkstart各体格指標におけるカットオフ值}

各体格指標におけるカットオフ值では Table 1,2 に示すように, 体厚, 体周囲長, 体重, BMI のいずれ も数值が高くなると, 加振強度が高くなる傾向を示し た. BMI に関して, カットオフ值 $25.3 \mathrm{~kg} / \mathrm{m}^{2}$ は, 普 通体重と前肥満の境に相当し, カットオフ值 $31.0 \mathrm{~kg} /$ $\mathrm{m}^{2}$ は前肥満と肥満 (1 度)の境に相当した。

\section{2-4 BMI におけるカットオフ值の妥当性の検討}

1-6 項の BMIに扔ける, 各カットオフ值での弾性率 測定不能領域に対する, 適切な加振強度の解析結果を Fig. 5 に示す. Figure $5 \mathrm{a}$ でのカットオフ值 $25.3 \mathrm{~kg} /$ $\mathrm{m}^{2}$ より下の BMI では加振強度 30\%に対して, 加振強 度 50, 70\%ともに有意差を認めた $(\mathrm{P}<0.001, \mathrm{P}<0.001)$. Figure 5b でのカットオフ值 25.3-31.0 kg/ $\mathrm{m}^{2}$ 区間で は, 加振強度 50\%に対して加振強度 70\%では有意差 を認め $(\mathrm{P}=0.001)$, 加振強度 $30 \%$ では有意差を認めな かった $(\mathrm{P}=0.13)$. Figure $5 \mathrm{c}$ でのカットオフ值 31.0 $\mathrm{kg} / \mathrm{m}^{2}$ を超える BMI では, 加振強度 70\%に対して加 振強度 $30 \%$ では有意差を認め $(\mathrm{P}=0.04)$, 加振強度 $50 \%$ では有意差を認めなかった $(\mathrm{P}=0.37)$.

\section{3. 考 察}

本研究では肝 MRE に㧈ける適切な加振強度と体格 指標との関係を明らかにするため, 加振強度 30,50 , 70\%を使用し，体格指標では体厚，体周囲長，体重， BMI の 4 項目で比較検討を行った. ROC 解析, ACU 值の比較結果より, BMI が最も適切な体格指標で, カットオフ值は加振強度 $30 \%$ と 50\%の境界で 25.3 $\mathrm{kg} / \mathrm{m}^{2}$, 加振強度 $50 \%$ と $70 \%$ の境界で $31.0 \mathrm{~kg} / \mathrm{m}^{2}$ で あった。この結果から，加振強度の設定はBMIにお いて, 普通体重以下で 30\%, 前肥満では 50\%, 肥満 (1 度) 以上では $70 \%$ が適切であることが示唆された，24 項に打ける解析結果より, カットオフ值 25.3-31.0 $\mathrm{kg} / \mathrm{m}^{2}$ 区間では, 加振強度 $50 \%$ に対して加振強度 $30 \%$ では有意な差は認められず，カットオフ值 31.0 $\mathrm{kg} / \mathrm{m}^{2}$ を超える BMI では, 加振強度 70\%に対して加 振強度 50\%では有意差を認めなかった。体格が小柄 になるほど, 強い加振強度設定は弾性率測定不能領域 が多くなることが示唆された．特にBMI 区分でのや せ型の体格では，加振強度設定が強くなると弾性率測 定不能領域が顕著に多くなるため, 加振強度設定には 気をつけなければならない.

先行研究では, Shinagawa らは10 名の健常ボラン ティアを対象に，加振強度とスライス厚をそれぞれ 70\%/8 mm, 70\%/10 mm, 50\%/8 mm, および50\%/10 $\mathrm{mm}$ を用いて 1 週間繰り返し, MRE 撮像の再現性を 検討したが，肝臓の弾性率に有意差はなく，95\%信頼 区間は $10 \%$ 以内であったと報告した ${ }^{7)}$. 彼らの研究で は, MRE の撮像条件として加振周波数 $60 \mathrm{~Hz}$, 加振強 
Cut-off value: less than $25.3 \mathrm{~kg} / \mathrm{m}^{2}$
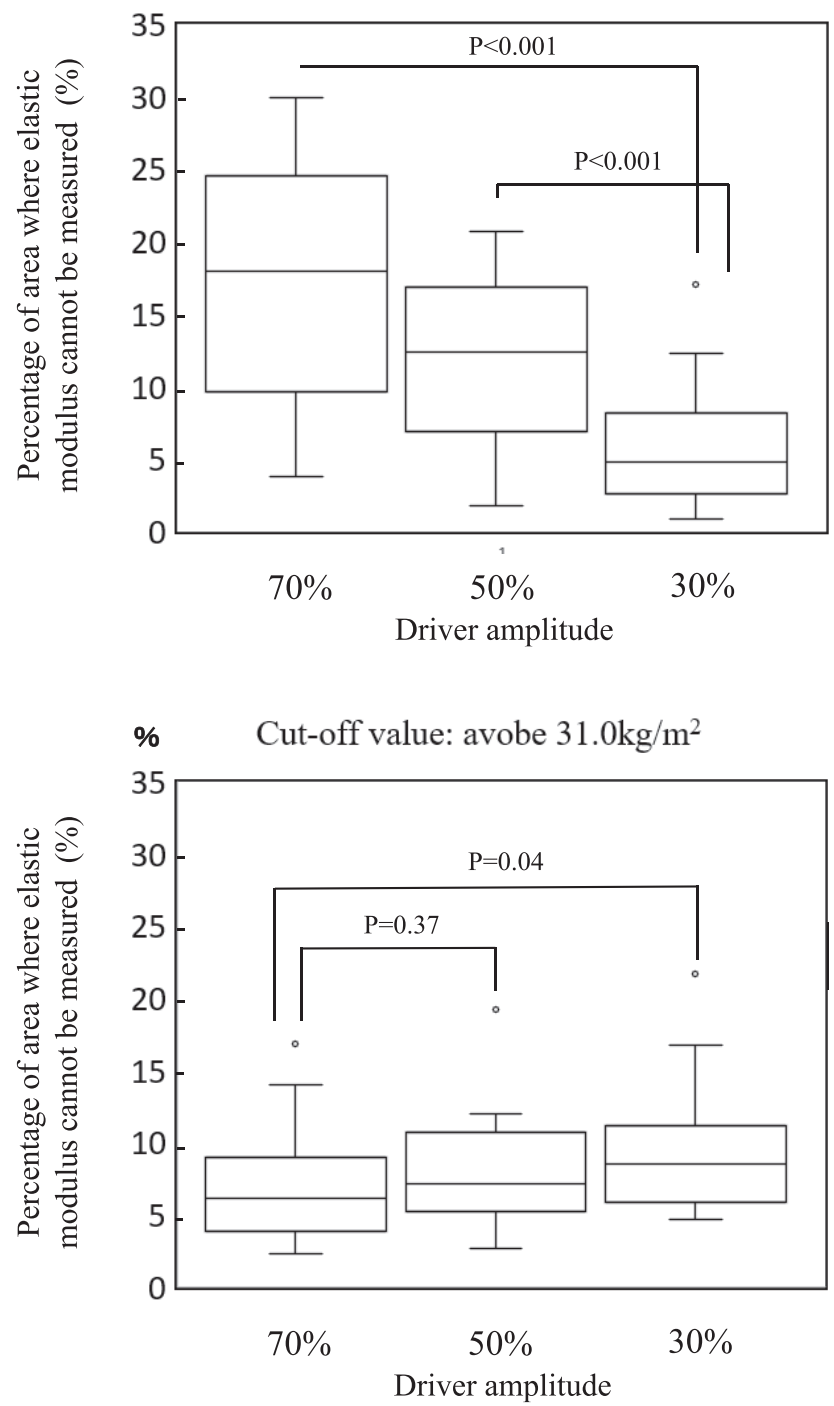

Cut- off value: $25.3-31.0 \mathrm{~kg} / \mathrm{m}^{2}$

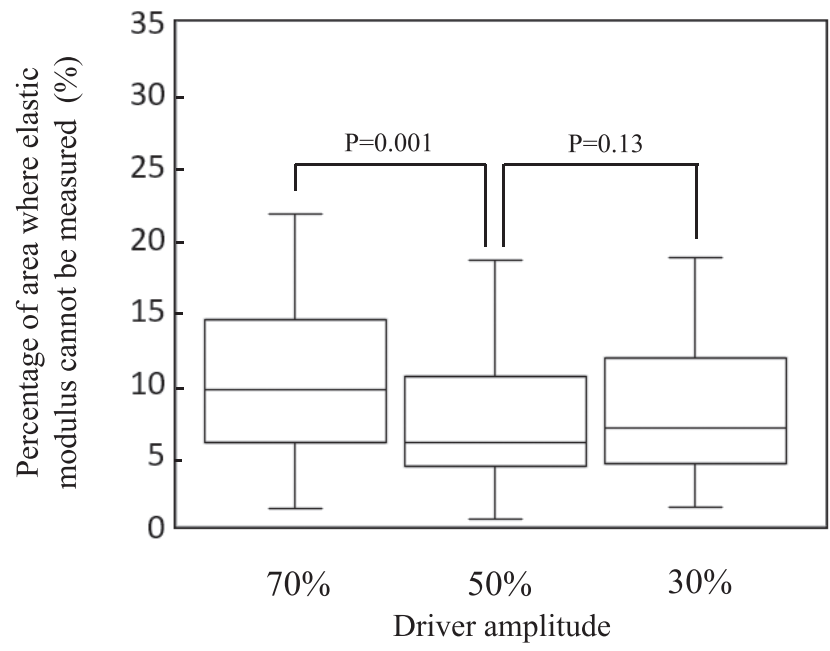

Fig. 5 Analysis result of appropriate driver amplitude for elastic modulus non-measurable area in BMI of each cutoff value section. The upper ends of boxes indicate the third quartile and the bottom ends of boxes the first quartile, and the lines in the box plot the median. The upper whiskers indicate the maximum and the lower whiskers the minimum, and the black coin is outliers.

度 50\%, MEG 周波数 $80 \mathrm{~Hz}$ ，スライス厚 8-10 mm を 推奨している，対してわれわれの検討は，体格に対す る適切な加振強度に注目し, 対象を 60 例の疾患を もった被験者群にすることにより，より現実に近い環 境での検討を行った.

本研究に打いて BMI が上昇すると, 適切な加振強 度も上昇することが明らかになった。その理由とし て, Fig. 6 が示すように体格が小柄な被検者に対して 加振強度が強すぎる場合, 肝臓に直接伝播する波, 反 射波, 屈折波が相互作用し, 波画像上に扔いて干涉縞, 画像欠損を生じる。これにより計算ミスが生じ，硬度 マップ上で cross-hatching 領域が多くなると考えられ る. 一方 Fig. 7 が示すように体格の大柄な被検者に 加振強度が弱すぎる場合は, 肝臟に直接伝播する波の
減衰が大きくなるため，波画像上で波がうまく付か ず，計算ミスが生じ硬度マップ上で cross-hatching 領 域が多くなるためと考えられる。よって体格に応じた 適切な加振強度を設定することにより，crosshatching 領域の少ない(計算ミスが少ない)硬度マッ プの取得が可能となり, より正確な弾性率の取得が可 能になることが期待できる，体格指標に関して，BMI が体周囲長や体重と比較し, 高い AUC 值を示した。 BMI は皮下厚測定やデュアルエネルギーX 線吸収法 (DXA)などから得られる, 直接的な体脂肪の測定値 と比較的高い相関を示し ${ }^{16.17)}$, 肥満度と BMI は非常に

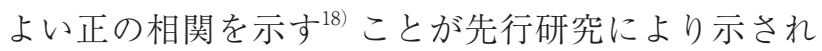
ているので，体格を適切に反映していると考えられ る. 更に BMI は身長, 体重から算出できる点で, 低体 

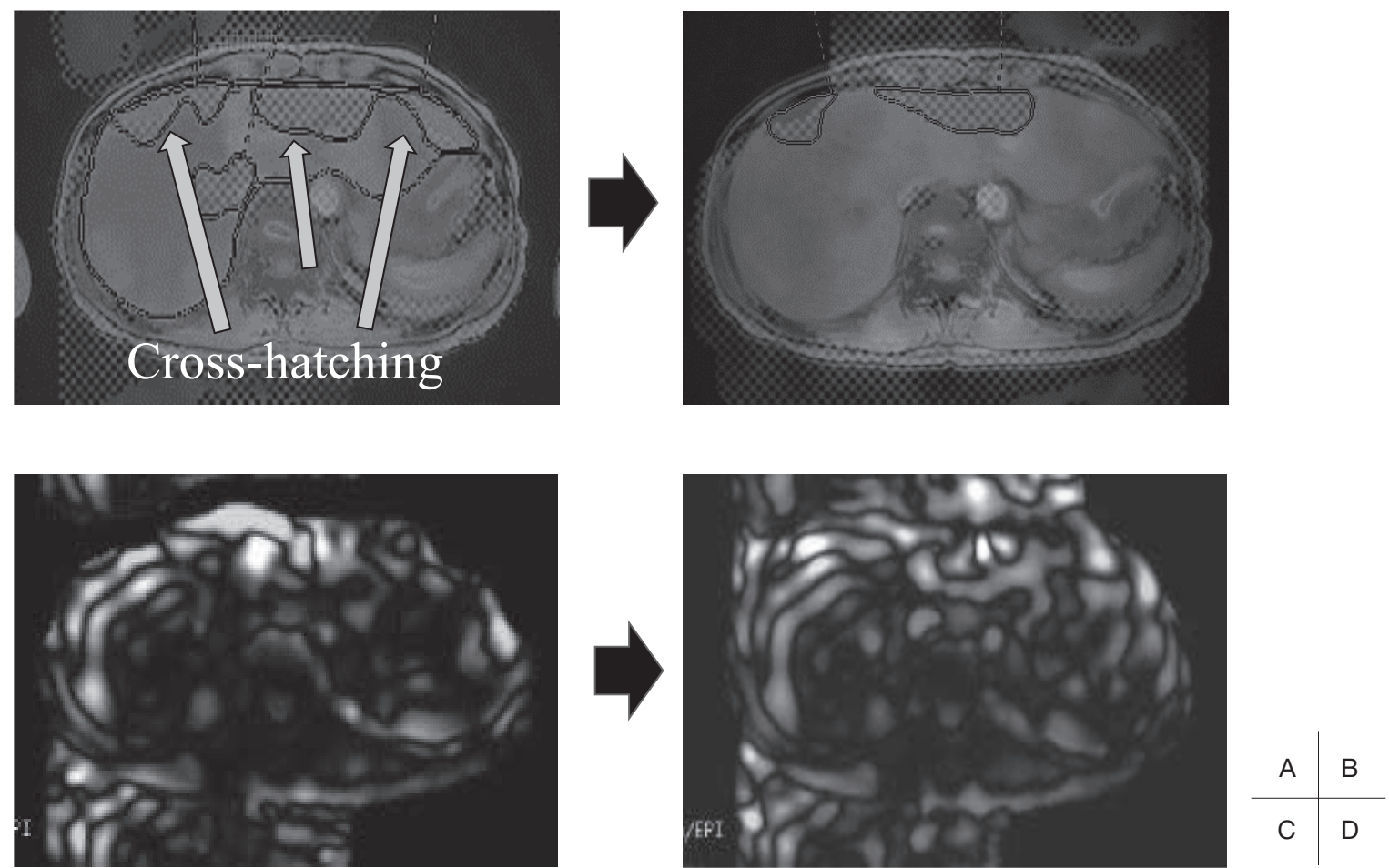

Fig. 6 MRE of small physique subject.

(A) Fused image of $70 \%$ amplitude applied to a lean subject

(B) Fused image of $30 \%$ amplitude applied to the same as (A) subject

(C) Wave image of $70 \%$ driver amplitude

(D) Wave image of $30 \%$ driver amplitude

MRE: magnetic resonance elastography
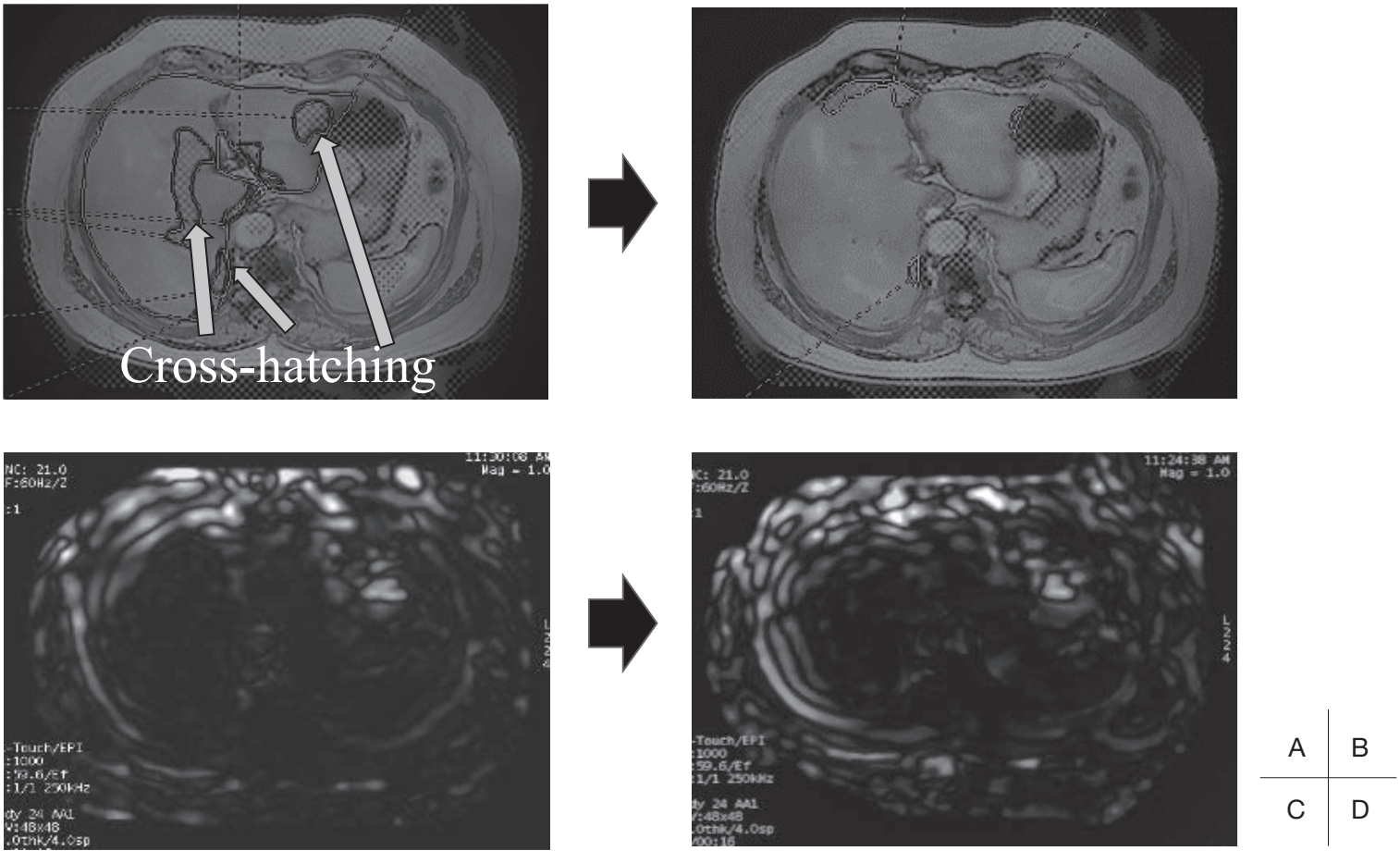

Fig. 7 MRE of large physique subject.

(A) Fused image of $30 \%$ amplitude applied to a large subject

(B) Fused image of $70 \%$ amplitude applied to the same as (A) subject

(C) Wave image of $30 \%$ driver amplitude

(D) Wave image of $70 \%$ driver amplitude

MRE: magnetic resonance elastography 
重, 正常体重, 過体重, 肥満などの体格を加味した体 重をカテゴリ分類するうえで，簡易的に利用できる． 以上より, BMI は他の 3 項目より肝 MRE を行ううえ で, 体格指標として適切であると考えられる。弾性率 を計測する際，肝臓の硬さを正確に測定するには主要 な血管，病変，および cross-hatching 領域を回避する 必要がある ${ }^{11}$. 特に横隔膜を介して肝内に入ってくる 多方向の波が，重複，干渉する部位で硬度マップ上の エラーが生じた場合に生じる hot spot や dark spot ${ }^{3)}$ を避けなければならない，本研究の成果として，体格 に合わせた加振強度を設定することで，弾性率測定不 能領域が少ない硬度マップを得ることが期待できる。 弾性率測定不能領域が少ないことは, 血管, 病状, アーチファクトを避けることが可能となり，正確な弾 性率が取得できると考えられる。

本研究の限界として, 第 1 に, gold standard である 肝生検との肝線維化の grade 比較は行っていない. 本来であれば今回得られた結果に, gold standardで ある肝生検との肝線維化の grade 比較を合わせて総 合的に評価することが理想であるが，当院において肝 MRE を行う症例数に比べて肝生検症例数が少なかっ たためである、今後, 症例数が集まり次第検討が必要 であると考えている，第 2 に, 最適な加振強度を求め るには，横隔膜を介して全周性に入ってくる多方向の 波が重複・干渉する部位で, 硬度マップの計算エラー が生じた場合に現れる hot spot や dark spot を考慮し たほうがよいが, cross-hatching として硬度マップ上
に明らかな弾性率測定不能領域が出ていない場合は計 測していない，第 3 に, 幅広い弾性率を示す肝疾患症 例を対象としているため, 肝硬変が進行している被検 者と重大な疾患のない正常な被検者を比較した際, BMI が同等であっても適切な加振強度が異なる可能 性がある。それらの関係については更なる検討が必要 であると考えている.

\section{4. 結 語}

肝 MRE において体格に対する適切な加振強度や, それを決定する際の適切な体格指標を明らかにするた め検討を行った。 その結果, 加振強度を決定する際の 体格指標はBMI を用いて, 加振強度 30\%が普通体型 以下， $50 \%$ が前肥満， $70 \%$ が肥満(1 度)を目安に設定 することが適切であると考えられる。

\section{謝 辞}

本研究に際しご協力いただいた旭川医科大学病院放 射線部の皆様に感謝申し上げます。

なお, 本研究の一部は第 47 回日本放射線技術学会 秋季学術大会(2019 年, 大阪)で発表した。

\section{利益相反}

筆頭著者および共著者全員に開示すべき利益相反は ない.

\section{参考文献}

1) Martínez SM, Crespo G, Navasa $M$, et al. Noninvasive assessment of liver fibrosis. Hepatology 2011; 53(1): 325-335.

2) Koike K, Tsutsumi T, Fujie H, et al. Molecular mechanism of viral hepatocarcinogenesis. Oncology 2002; 62(Suppl 1): 29-37.

3) 吉満研吾, 中島淳, 本杉宇太郎 編. 肝臓疾患診断に扔け る MRE ハンドブック．東京：診断と治療社, 2015.

4) Motosugi U, Ichikawa $T$, Sano K, et al. Magnetic resonance elastography of the liver: preliminary results and estimation of inter-rater reliability. Jpn J Radiol 2010; 28(8): 623-627.

5) Huwart L, Sempoux C, Salameh N, et al. Liver fibrosis: noninvasive assessment with MR elastography versus aspartate aminotransferase-to-platelet ratio index. Radiology 2007; 245 (2): 458-466.

6) Venkatesh SK, Yin M, Ehman RL. Magnetic resonance elastography of liver: technique, analysis, and clinical applications. J Magn Reson Imaging 2013; 37(3): 544-555.

7) Shinagawa $Y$, Mitsufuji $T$, Morimoto $S$, et al. Optimization of scanning parameters for MR elastography at $3.0 \mathrm{~T}$ clinical unit: volunteer study. Jpn J Radiol 2014; 32(7): 441-446.

8) Itoh $Y$, Takehara $Y$, Kawase $T$, et al. Feasibility of magnetic resonance elastography for the pancreas at 3T. J Magn Reson Imaging 2016; 43(2): 384-390.
9) World Health Organization. Obesity: preventing and managing the global epidemic. Report of a WHO consultation. World Health Organ Tech Report Series 894: 2000.

10) Venkatesh SK, Wang G, Teo LL, et al. Magnetic resonance elastography of liver in healthy Asians: normal liver stiffness quantification and reproducibility assessment. J Magn Reson Imaging 2014; 39(1): 1-8.

11) Mitsufuji $T$, Shinagawa $Y$, Fujimitsu R, et al. Mesurement consistency of MR elastography at 3.0 T: comparison among three different region-of-interest placement methods. Jpn J Radiol 2013; 31(5): 336-341.

12）斎藤茂芳, 田中景子, 橋渡貴司. MR エラストグラフィ： 異なる 2 種類の直接逆問題再構成法による肝弾性率測定. 日放技学誌 2016; 72(2): 128-138.

13) Silva AM, Grimm RC, Glaser KJ, et al. Magnetic resonance elastography: evaluation of new inversion algorithm and quantitative analysis method. Abdom Imaging 2015; 40 (4): 810-817.

14) Yoshimitsu K, Mitsufuji $T$, Shinagawa $Y$, et al. MR elastography of the liver at 3.0 $\mathrm{T}$ in diagnosing liver fibrosis grades; preliminary clinical experience. Eur Radiol 2016; 26(3): 656-663. 
15) Sing $T$, Sander O, Beerenwinkel N, et al. ROCR: visualizing classifier performance in R. Bioinformatics 2005; 21(20): 39403941. (2020 年 5 月 31 日確認).

16) Garrow JS, Webster, J. Quetelet's index $\left(\mathrm{W} / \mathrm{H}_{2}\right)$ as a measure of fatness. Int J Obes 1985; 9(2): 147-153.

17) Freedman DS, Horlick M, Berenson GS. A comparison of the
Slaughter skinfold-thickness equations and BMI in predicting body fatness and cardiovascular disease risk factor levels in children. Am J Clin Nutr 2013; 98(6): 1417-1424.

18）新井俊彦。肥満度， BMI および体脂肪率の各種疾患との 相関による危険因子としての評価。健康医 1999-2000; 14 (2): 168-173. 